\title{
Fate of herpes simplex virus in lymphocytes from blood and joint effusions of systemic and pauciarticular juvenile chronic arthritis
}

\author{
P. HOLLINGWORTH, D. J. A. APPLEFORD, B. M. ANSELL, AND \\ A. M. DENMAN
}

From the Division of Rheumatology, Clinical Research Centre, Watford Road, Harrow, Middlesex HA1 3UJ

SUMmARY The fate of herpes simplex virus (HSV) in the lymphocytes of patients with juvenile chronic arthritis (JCA) was studied by previously described methods. Lymphocytes isolated from blood and joint effusions of 18 patients with systemic JCA and 11 patients with pauciarticular JCA usually supported viral growth normally.

The clinical features of systemic juvenile chronic arthritis (JCA), namely, fever, rash, and lymphadenopathy, strongly suggest infection. To date no bacterial infection has been substantiated, and while viral causes are postulated there is little direct evidence apart from a single instance of isolation of rubella virus from the joint effusion of such a patient. $^{1}$

Evidence supporting a viral pathogenesis for other connective tissue diseases includes the observation that certain immunopathological phenomena seen in these disorders also occur in known viral infections. For example, herpes simplex virus (HSV) invariably grows in vitro in lymphocytes from healthy individuals ${ }^{2}$ but fails to grow in lymphocytes from donors with recurrent severe cold sores or infectious mononucleosis, a phenomenon attributed to viral intereference. ${ }^{3}$ Because lymphocytes from patients with connective tissue diseases also frequently fail to support the growth of HSV used as an indicator virus, we have postulated that these cells are engaged in an antiviral response or are harbouring a persistent virus infection. ${ }^{4}$

Related studies have shown that lymphocytes isolated from effusions of patients with rheumatoid arthritis failed to support growth of HSV whereas blood lymphocytes from the same individuals supported growth of HSV to the expected titre. ${ }^{5}$ This nonpermissiveness was consistent with viral interference, and nonspecific factors attributed to residence in inflammatory fluid were so far as possible excluded.

Accepted for publication 10 December 1981.

Correspondence to Dr A. M. Denman.
This paper reports similar studies seeking indirect evidence for a viral aetiology in patients with JCA.

\section{Materials and methods}

Clinical material. Blood samples and knee effusions were obtained from 18 patients with systemic JCA and 11 patients with pauciarticular JCA, the patients fulfilling accepted criteria for diagnosis. ${ }^{6}$ All patients had active disease; 4 with systemic disease were receiving prednisolone and the remainder nonsteroidal anti-inflammatory drugs.

\section{IMMUNOLOGICAL METHODS}

Isolation of mononuclear cells. Joint fluids were mixed with acid citrate dextrose solution giving a final concentration of $0.0018 \mathrm{~g} / \mathrm{ml}$ dextrose and $0.002 \mathrm{~g} / \mathrm{ml}$ citrate, incubated with $75 \mathrm{IU} / \mathrm{ml}$ hyaluronidase (Fisons) for 30 minutes, then washed in buffered salt solution (PBSA). Blood samples were anticoagulated with $20 \mathrm{IU} / \mathrm{ml}$ of preservativefree heparin. Mononuclear cells from both sources were isolated by density gradient separation on Ficoll/Triosil, ${ }^{7}$ washed twice, and resuspended in Roswell Park Memorial Institute (RPMI) 1640 medium, supplemented with $12.6 \mathrm{~g} / \mathrm{l}$ bicarbonate, 5 mM HEPES, 2 mM L-glutamine, $10 \%$ fetal calf serum (FSC), and $50 \mathrm{mg} / \mathrm{ml}$ gentamicin. Only effusion cultures containing more than $50 \%$ lymphocytes were studied.

Mitogen stimulation. Suspensions of mononuclear cells at a concentration of $10^{6}$ cells $/ \mathrm{ml}$ were stimulated with phytohaemagglutinin (PHA: Wellcome 


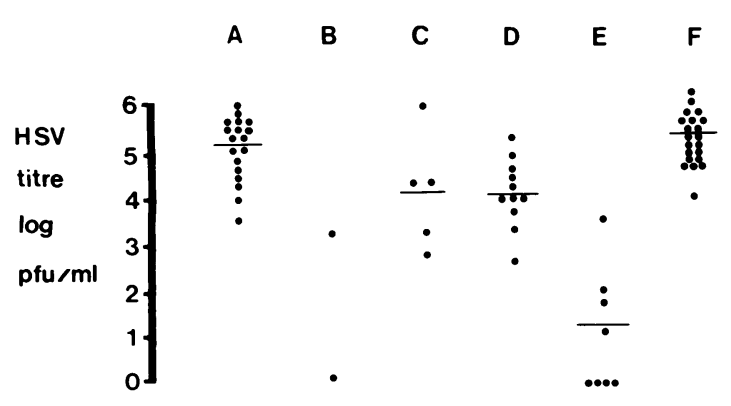

Fig. 1 Growth of HSV in blood and effusion lymphocytes: maximum titre by the fifth day after infection. A. Systemic JCA, blood lymphocytes. B. Systemic JCA, effusion

lymphocytes. C. Pauciarticular JCA, blood lymphocytes. D. Pauciarticular JCA, effusion lymphocytes.

E. Rheumatoid arthritis, effusion lymphocytes. ${ }^{4} \mathrm{~F}$. Healthy controls and patients with a variety of diseases other than connective tissue disease. ${ }^{2}$

Mean titres of growth of HSV in lymphocytes: Control blood, $\log 5 \cdot 3 ;$ systemic JCA blood, $\log 5 \cdot 0, N S$ (Student's $t$ test). Rheumatoid arthritis effusion $\log 1 \cdot 0$; pauciarticular JCA effusion, $\log 4 \cdot 0, P<0 \cdot 005$.

purified grade) at $0.8 \mu \mathrm{g} / 10^{6}$ cells. The stimulation index was assayed by ${ }^{14} \mathrm{C}$-thymidine uptake over an 18 -hour period, 48 hours after mitogen stimulation. ${ }^{8}$

Differential counts. These were performed on cytocentrifuge preparations stained with MayGrünwald-Giemsa.

Cell viability. This was measured by $0 \cdot 1 \%$ trypan blue exclusion.

VIROLOGICAL METHODS

Virus stocks. The HFEM stain of HSV type 1 was propagated in primary chick embryo fibroblasts. ${ }^{9}$

Infection of mononuclear cells. Mononuclear cells at a concentration of $10^{6}$ viable cells $/ \mathrm{ml}$ were infected with HSV at a multiplicity of infection of $0 \cdot 1$ virus particles per cell. The cell suspensions were transferred to flat-bottomed vials, $0 \cdot 3 \times 10^{6} \mathrm{cells} / \mathrm{vial}$, and triplicate samples were frozen at $-70^{\circ} \mathrm{C}$ on days $0-5$ after infection.

Measurement of virus titres. The suspensions of mononuclear cells were repeatedly frozen and thawed and virus was titrated by the semimicro plaque assay method ${ }^{10}$ using primary chick embryo fibroblast monolayers.

\section{Results (Fig. 1)}

Blood lymphocytes from 15 of 18 patients with systemic JCA and 3 of 5 patients with pauciarticular JCA supported viral growth normally. Three of these patients were taking prednisolone.

Infectivity titres in lymphocytes from joint effusions of 11 patients with pauciarticular JCA were slightly less than control blood samples. Titres in lymphocytes from blood and effusion samples taken at the same time were similar. Only 2 effusions from systemic JMA were suitable for study. Lymphocytes isolated from blood and joint effusions showed a brisk proliferative response to PHA and there was no correlation between the extent of this response and virus growth.

\section{Discussion}

The failure of rheumatoid synovial effusion lymphocytes to support the growth of HSV has been advanced as possible evidence for a viral aetiology of rheumatoid arthritis. ${ }^{4}$ However, the results obtained with effusion lymphocytes from patients with JCA contrast with these earlier results, since HSV titres obtained in cultures of synovial effusion lymphocytes from patients with JCA were only slightly lower than those obtained in blood lymphocyte cultures. As lymphocytes exposed to the inflammatory JCA synovial effusions supported the growth of HSV normally, it is unlikely that exposure of inflammatory synovial fluid in itself influences the outcome. Moreover a variety of control experiments also excluded this possibility. ${ }^{4}$

Two other possible explanations for the nonpermissiveness of rheumatoid synovial effusion lymphocytes must be considered in the present context. The first concerns the role of viral interference. These studies were originally undertaken to see whether lymphocytes isolated from the blood and inflammatory effusions of patients with chronic polyarthritis would display viral interference, that is, prove to be specifically resistant to infection by viruses implicated in the pathogenesis of the disease. Some specificity was indeed demonstrated, since lymphocytes isolated from patients with rheumatoid arthritis and inflammatory connective tissue diseases which failed to support the growth of HSV supported the growth of vesicular stomatitis virus and measles virus. Conversely, HSV grew normally in lymphocytes isolated from patients with rubella arthritis and other undetermined, short-lived, post-infective arthritides. ${ }^{+}$Insufficient cells were isolated from the synovial effusions of patients with JCA to allow a range of viruses to be treated. However, the normal growth of HSV in effusion cells from patients with pauciarticular JCA emphasises that different patterns of virus growth are observed in lymphocytes cultured from patients with different forms of inflammatory arthritis and strengthens the possibility that these differences are related to persistent infection by disparate viruses.

Secondly, interferon production may have protected the effusion lymphocytes of patients with 
rheumatoid arthritis from infection with HSV. This possibility is largely discounted, firstly, because interferon titres in nonpermissive cultures from rheumatoid synovial effusions were not significantly different from those obtained in permissive cultures, and, secondly, because vesicular stomatitis virus, an agent which is more susceptible to inhibition by interferon than HSV, grew to expected titres in such cultures. ${ }^{4}$ However, recent observations suggest that this possiblity must be re-examined: interferon has been detected in the blood and synovial effusions of patients with chronic arthitis, ${ }^{11}$ and viral interference may itself be produced by low level production of interferon which cannot be detected by standard techniques. ${ }^{12}$ Defective interferon production in JCA synovial effusions could account for the susceptibility of lymphocytes from this source to HSV infection. There is already some evidence that interferon production may be defective in patients with some systemic connective tissue diseases. ${ }^{13}$ The different fate of herpes simplex virus in synovial effusion lymphocytes of patients with adult rheumatoid arthritis and with juvenile chronic arthritis suggests that the abnormal behaviour of this virus in the former disease is a specific abnormality and that studies of this kind with other candidate viruses can be used to investigate a possible viral aetiology for these disorders.

\section{References}

${ }^{1}$ Smith M F, Haycock G B, Grahame R. Rubella and juvenile chronic arthritis. Arch Dis Child 1981; 56: 310-1.
2 Denman A M, Fialkow P J, Pelton B K, Salo A O, Appleford D J. Attempts to establish a viral aetiology for Behcet's syndrome. In: Lehner T H, Barnes C G, eds. Behçet's Syndrome: Clinical and Immunological Features. London: Academic Press, 1979; 91-105.

${ }^{3}$ Denman A M, Pelton P K, Appleford D J A, Kingsley M. Virus infections of lympho-reticular cells and auto-immune disease. Transplant Rev 1976; 31: 79-115.

4 Appleford D J A, Denman A M. Fate of herpes simplex virus in lymphocytes from inflammatory joint effusions. II. Mechanisms of non-permissiveness. Ann Rheum Dis 1979; 38: 450-5.

${ }^{5}$ Appleford D J A, Denman A M. Fate of herpes simplex virus in lymphocytes from patients with inflammatory joint effusions. I. Failure of virus to grow in cultured lymphocytes. Ann Rheum Dis 1979; 38: 443-9.

${ }^{6}$ Ansell B M. Chronic arthritis in childhood. Ann Rheum Dis 1978; 37: 107-20.

7 Boyum A. Separation of leucocytes from blood. Scand J Clin Lab Invest 1968; 21: suppl 97.

8 Janossy G, Greaves M F. Lymphocyte activation. I. Response of T and B lymphocytes to phytomitogens. Clin Exp Immunol 1971; 9: 483-8.

9 Schmidt N J. In: Lennette E H, Schmidt N J, eds. Diagnostic Procedures for Viral and Rickettsial Infection. Chapter 3. New York: American Public Health Association, 1969.

${ }^{10}$ Zisman B, Merigan T C. A useful quantitative semi-micro method for viral plaque assay. Proc Soc Exp Biol Med 1973; 142: 1174-9.

$"$ Hooks J J, Moutsopoulos H M, Geis S A, Staht N I, Decker J L, Notkins A L. Immune interferon in the circulation of patients with autoimmune disease. $N$ Engl J Med 1979; 301: 5-8.

${ }^{12}$ Sekellick M J, Marcus P I. Persistent infection. I. Interferoninducing defective-interfering particles as mediators of cell sparing: possible role in persistent infection by vesicular stomatitis virus. Virology 1978; 85: 175-86.

${ }^{13}$ Neighbour P A, Grayzel A I. Interferon production in vitro by leucocytes from patients with systemic lupus erythematosus and rheumatoid arthritis. Clin Exp Immunol 1981; 45: 576-82. 